Additional Perspectives articles for Influenza: The Cutting Edge book collection are available at http://perspectivesinmedicine.cshlp.org/cgi/collection/influenza_the_cutting_edge.

\title{
Ferreting Out Influenza Virus Pathogenicity and Transmissibility: Past and Future Risk Assessments in the Ferret Model
}

\author{
Jessica A. Belser, Joanna A. Pulit-Penaloza, and Taronna R. Maines \\ Influenza Division, National Center for Immunization and Respiratory Diseases, Centers for Disease Control \\ and Prevention, Atlanta, Georgia 30329, USA \\ Correspondence: jbelser@cdc.gov
}

\begin{abstract}
As influenza A viruses continue to jump species barriers, data generated in the ferret model to assess influenza virus pathogenicity, transmissibility, and tropism of these novel strains continues to inform an increasing scope of public health-based applications. This review presents the suitability of ferrets as a small mammalian model for influenza viruses and describes the breadth of pathogenicity and transmissibility profiles possible in this species following inoculation with a diverse range of viruses. Adaptation of aerobiology-based techniques and analyses have furthered our understanding of data obtained from this model and provide insight into the capacity of novel and emerging influenza viruses to cause human infection and disease.
\end{abstract}

nfluenza A viruses represent a persistent public health threat. Annual epidemics in humans are associated with a high burden of disease, with estimations of 3-5 million cases of severe illness and $\sim 500,000$ deaths worldwide each year (Iuliano et al. 2018; Krammer et al. 2018). Human infection with influenza viruses from zoonotic reservoirs, although sporadic and typically self-limiting, nonetheless represent opportunities for acquisition of adaptations that could facilitate increased fitness to human hosts (Uyeki et al. 2017). Pandemics of influenza virus have likely occurred for centuries, with four well-documented pandemics in the twentieth and twenty-first centuries, a result of adaptation of avian-like viruses to mammals and gene reassortment between avian, swine, and human in- fluenza viruses (Morens and Taubenberger 2011). With an extensive diversity of hemagglutinin (HA) subtypes circulating in wild bird populations, and establishment of antigenically distinct $\mathrm{H} 1$ and $\mathrm{H} 3$ subtype viruses in the swine reservoir, there is a clear need for continued surveillance and study of novel and emerging influenza viruses to which humans lack immunity and, as such, represent a potential pandemic risk (Lycett et al. 2019; Pulit-Penaloza et al. 2019a).

Considering the diversity of emerging influenza viruses that pose a threat to human health, risk assessment rubrics are used by public health agencies to inform pandemic preparedness efforts. These rubrics (which include the Centers for Disease Control and Prevention [CDC] In-

Editors: Gabriele Neumann and Yoshihiro Kawaoka

Additional Perspectives on Influenza: The Cutting Edge available at www.perspectivesinmedicine.org

Copyright (C) 2020 Cold Spring Harbor Laboratory Press; all rights reserved; doi: 10.1101/cshperspect.a038323

Cite this article as Cold Spring Harb Perspect Med 2020;10:a038323 
J.A. Belser et al.

fluenza Risk Assessment Tool [IRAT] and World Health Organization [WHO] Tool for Influenza Pandemic Risk Assessment [TIPRA]) consider virus, host, and ecological properties (Trock et al. 2012; WHO 2016); assessments of pathogenicity and transmissibility in a mammalian model are included in both IRAT and TIPRA rubrics. Within this framework, in vivo evaluation of influenza viruses with pandemic potential is essential as virus pathogenicity and transmissibility represent multifactorial traits and cannot be studied fully outside a living host. In this vein, influenza virus represents just one of numerous respiratory viruses studied in the ferret model, with models established for paramyxoviruses, coronaviruses, and other pathogens using this species (Enkirch and von Messling 2015).

Data obtained from the ferret model informs a wide array of public health and research activ- ities pertaining to influenza viruses (Fig. 1). It is essential to consider the spectrum of applications supported by this species and how results gleaned from individual experiments can inform and contribute to these activities as a whole. Here, we provide an overview of the wealth of information generated from experimentation in the ferret model, emphasizing the critical role this species plays in current pathogenicity and transmissibility assessments of novel and emerging influenza viruses. Concurrently, we discuss efforts that aim to refine and improve the ferret model, particularly in the context of recent advances in aerobiology and molecular biology. As influenza viruses continue to jump the species barrier to cause human infection, continued investment in understanding how ferrets can best recapitulate the threat posed by these viruses to human health represents a necessary effort.

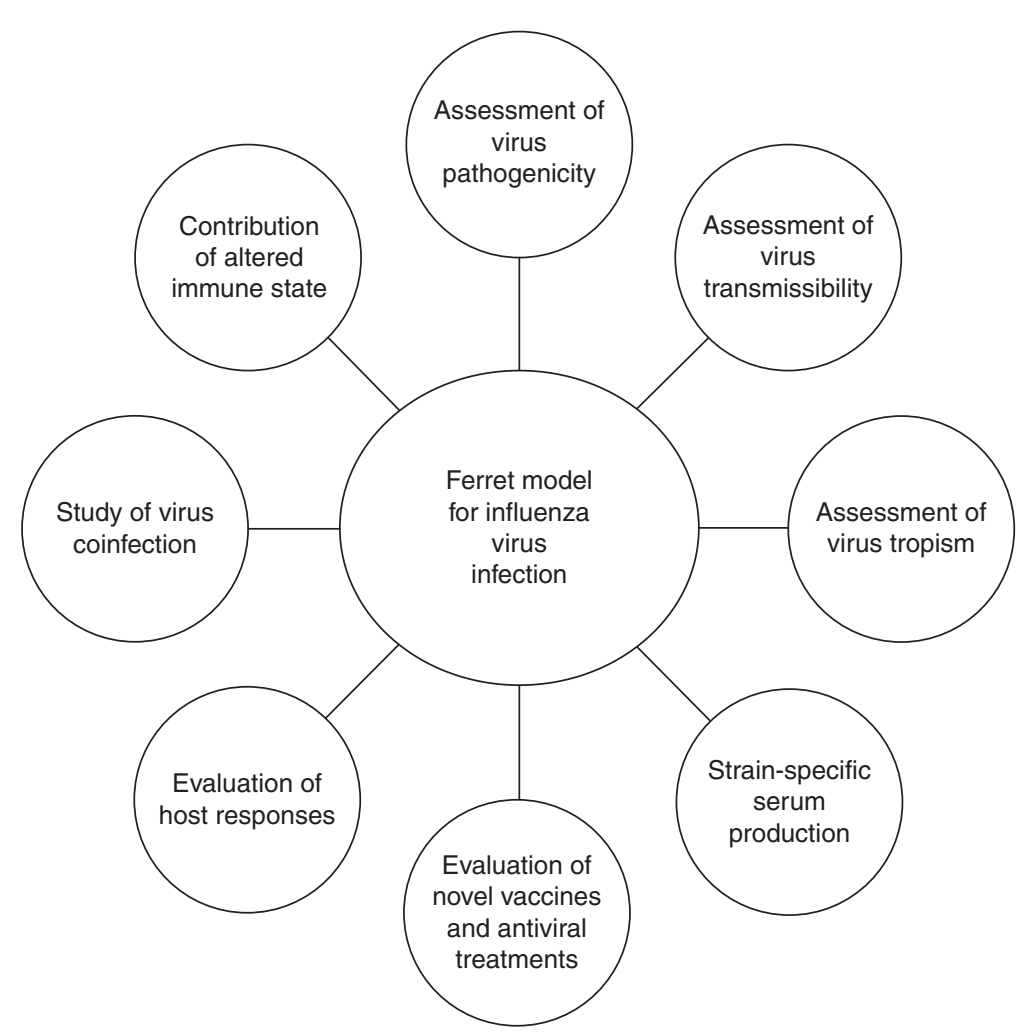

Figure 1. Selected applications of the ferret model for the study of influenza viruses. Applications are described in detail in the text. 


\section{INFLUENZA VIRUS PATHOGENICITY IN FERRETS}

Research reports describing infection of ferrets with influenza viruses date to the 1930s (Shope 1934). The natural susceptibility of ferrets to most influenza viruses is attributed to several key features. Humans and ferrets share generally comparable lung physiology, and possess similarities in the distribution and linkage types of sialic acid moieties present throughout the respiratory tract of both species (Jayaraman et al. 2012; Jia et al. 2014; $\mathrm{Ng}$ et al. 2014). In support of this, general agreement in binding patterns of human and avian influenza viruses to respiratory tract tissues in both species have been identified (Shinya et al. 2006; van Riel et al. 2006). As such, most human and zoonotic influenza viruses are capable of productive replication in the ferret, and present with clinical signs and symptoms of infection following high-dose intranasal inoculation, without the need for prior host adaptation (Belser et al. 2016). In contrast, the mouse model does not generally support virus replication of seasonal human influenza viruses; the guinea pig model can become productively infected with a range of influenza viruses, but animals do not present with most clinical signs or symptoms of influenza-like illness during infection (Belser et al. 2011).

The scope of influenza A viruses evaluated in ferrets has expanded greatly since the model was first characterized. Human influenza viruses $(\mathrm{H} 1, \mathrm{H} 2$, and $\mathrm{H} 3$ seasonal, epidemic viruses isolated from humans) typically cause mild disease in this model, characterized by low body-weight loss (generally $<5 \%$ of preinoculation weight), transient fever (typically defined as an increase in body temperature by $>1^{\circ} \mathrm{C}$ above preinoculation levels), and sneezing or rhinorrhea during the acute phase of infection (see references in Table 1). Virus replication is typically restricted to the upper respiratory tract (Fig. 2). Selected viruses are capable of replication in the lung, and occasional detection of infectious virus in the olfactory bulb is not uncommon (likely attributed to spillover from virus replication in the olfactory epithelium) (Zitzow et al. 2002; Schrauwen et al. 2012). Pandemic influenza vi-
Influenza Virulence and Transmissibility in Ferrets

ruses (such as the reconstructed 1918 or the 2009 H1N1 viruses) may be associated with higher viral titers and increased morbidity in this model (Table 1). However, systemic spread beyond the respiratory tract is rare, with the exception of occasional virus detection in gastrointestinal samples (Maines et al. 2009).

The detection and subsequent study of human cases of highly pathogenic avian influenza (HPAI) H5 and H7 subtype influenza viruses showed that the ferret model could recapitulate the severe disease associated with human infection with these viruses. In contrast to seasonal human influenza viruses, selected HPAI H5 and $\mathrm{H} 7$ viruses can be associated with moderate $(5 \%-15 \%)$ or severe $(>15 \%)$ mean maximum weight loss in ferrets postinoculation, with lethal infection possible depending on the inoculum strain (see references in Table 1). High sustained fevers are not uncommon, and presentation of additional clinical signs and symptoms of infection (including but not limited to inappetence and lethargy) may occur. Extrapulmonary virus detection is possible, including spread to the brain (Belser et al. 2007; Yen et al. 2007; Pearce et al. 2017); disease may progress to include neurological complications necessitating humane euthanasia (Maines et al. 2005).

In recent years, there has been an escalation of reported interspecies transmission of influenza A viruses resulting in human infection (Uyeki et al. 2017; Subbarao 2019). These include avian H5 subtype influenza viruses (predominantly but not exclusively HPAI H5N1) (Hamid et al. 2018), both low pathogenic avian influenza (LPAI) and HPAI H7N9 viruses, and swine influenza viruses isolated from humans (termed variant viruses) (Pulit-Penaloza et al. 2019a). This diversity has necessitated heightened evaluation of novel and emerging influenza viruses in ferret pathogenesis and transmission models, as antigenic and genetic assessments of these strains cannot uniformly predict relative levels of mammalian virulence. Although most zoonotic influenza viruses cause mild-to-moderate virulence in the ferret, severe disease is possible depending on the inoculum strain (see references in Table 1). The continued ability of these antigenically distinct influenza viruses to cause 

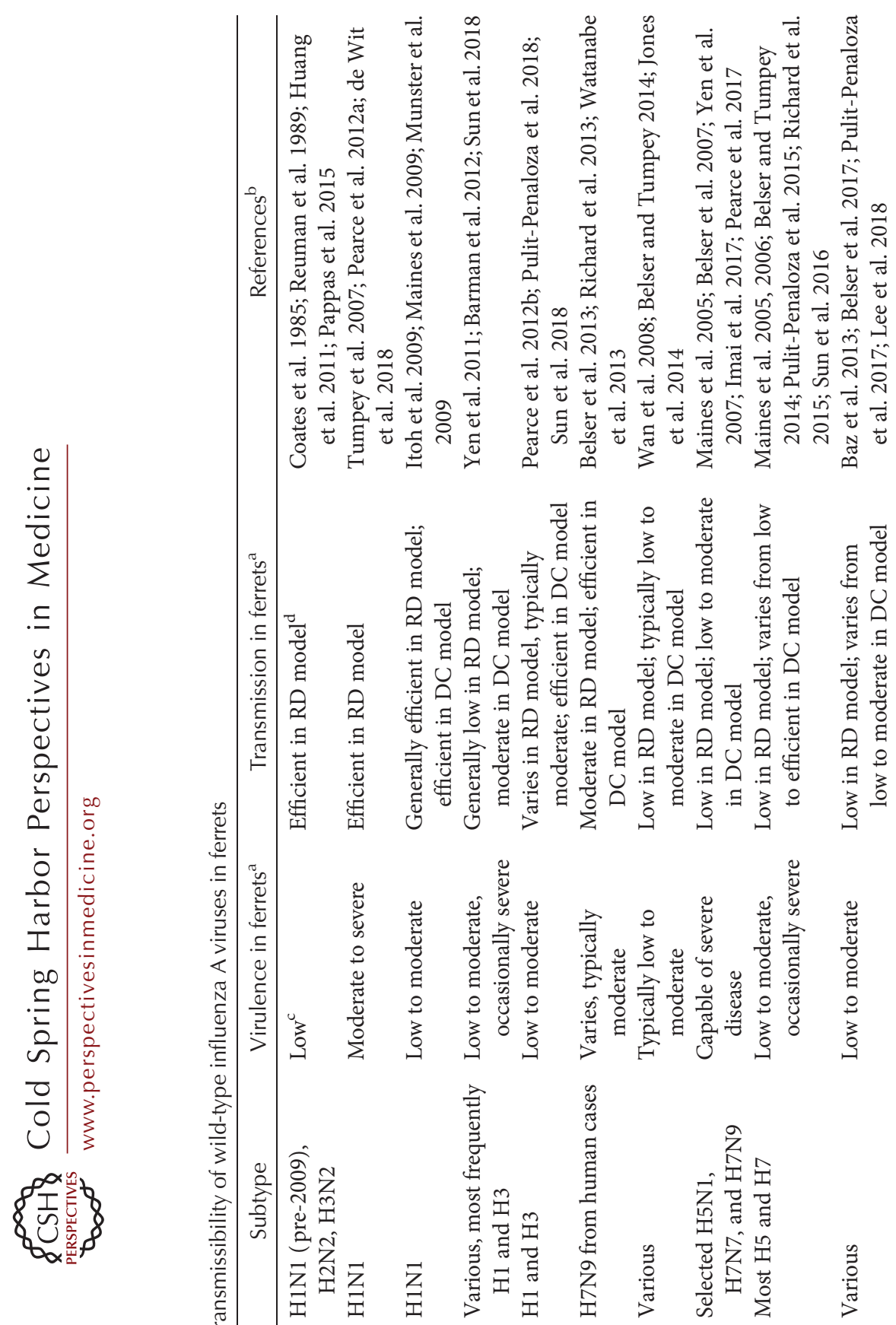

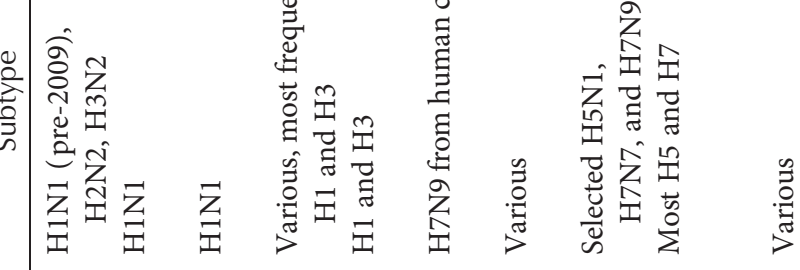

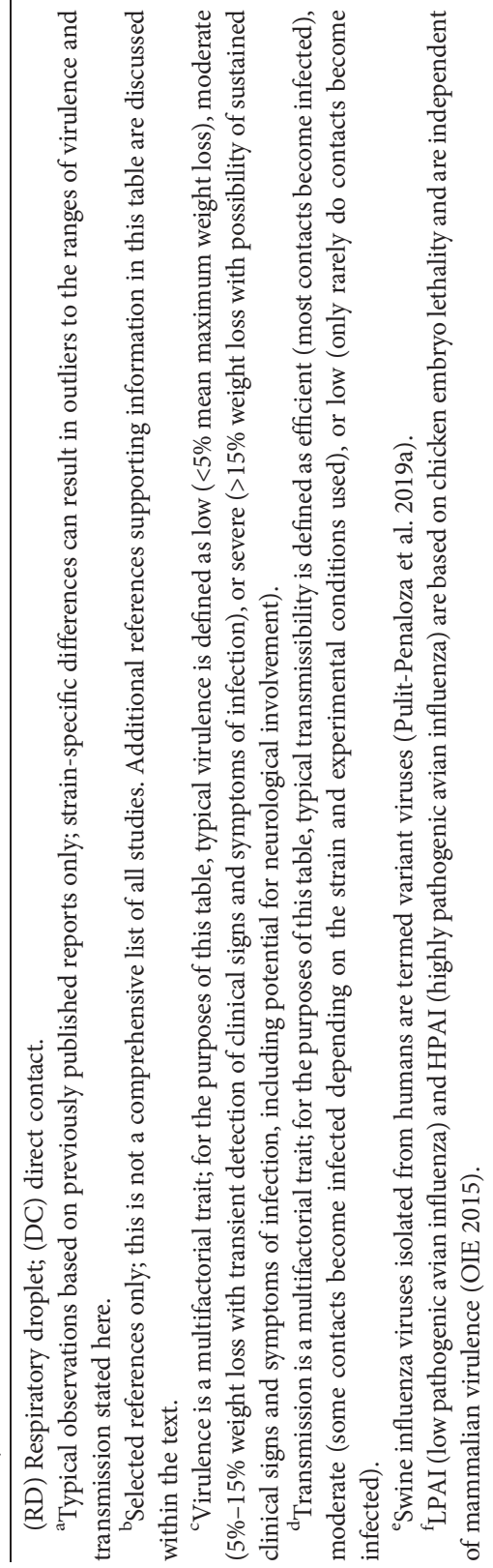




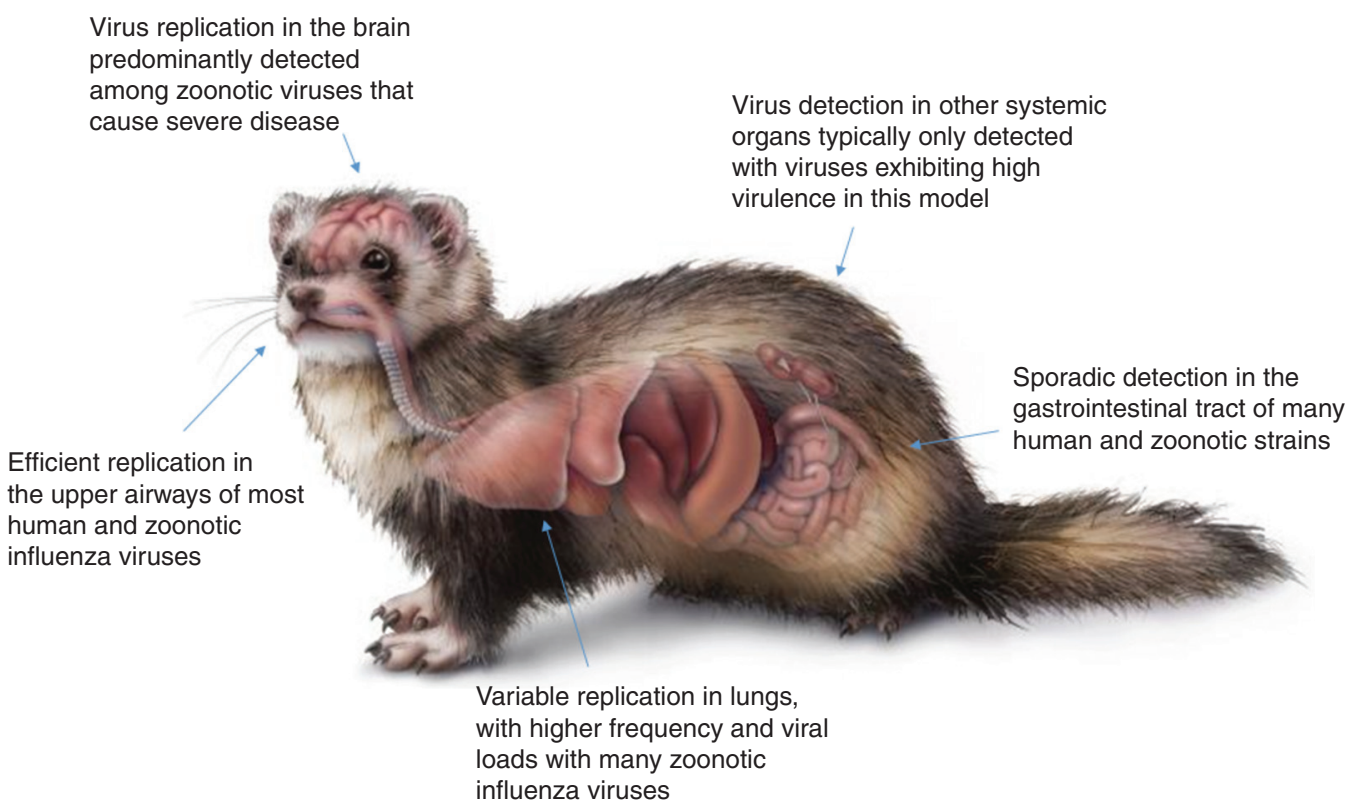

Figure 2. Scope and frequency of influenza A virus replication in experimentally inoculated ferrets. References are provided in Table 1. (The ferret illustration in this figure was by the U.S. Centers for Disease Control and Prevention and is freely available in the Public Health Image Library [PHIL].)

productive infection in humans (and ferrets), even in the absence of severe disease, highlights the public health threat posed by viruses from zoonotic reservoirs.

Assessments of virus pathogenicity in the ferret have historically been characterized by detection of infectious virus in respiratory tract and extrapulmonary tissues during the acute phase of infection (Zitzow et al. 2002; Belser et al. 2016) and immunohistochemical evaluation of tissues (Kuiken et al. 2010). However, recent efforts leading to the elucidation of ferret genome sequences (Peng et al. 2014) and ongoing development of species-specific reagents (Kirchenbaum and Ross 2017) have improved the capacity of this model to explore in more detail host immune responses postinfection. For example, investigation of ferret cytokine levels by semiquantitative reverse transcription polymerase chain reaction (RT-PCR) revealed differences in induction of proinflammatory cytokines and chemokines in respiratory tract tissues, depending on the severity of disease and the strain used for inoculation, which helped to identify correlations between transmission and local innate immune responses in the ferret upper respiratory tract (Svitek et al. 2008; Maines et al. 2012). Furthermore, evaluation of lymphocyte trafficking and T-cell responses following influenza virus infection are now possible in this species (DiPiazza et al. 2016; Music et al. 2016; Reber et al. 2018); a greater understanding of cell-mediated immune responses is critical as ferrets play an increasing role in preclinical evaluation of novel vaccine approaches (Margine and Krammer 2014). Ongoing sophistication and innovation of laboratory modeling methods will continue to improve our measurements and assessments of influenza virus pathogenicity in this species.

\section{INFLUENZA VIRUS TRANSMISSIBILITY IN FERRETS}

Pandemic influenza viruses emerge when three principal criteria are met: There must be little to no preexisting immunity to the virus in the human population, the virus must be capable of causing a productive infection in humans, and the virus must be able to spread from person to 
J.A. Belser et al.

person (Belser et al. 2010). Many zoonotic influenza A viruses possess the first two criteria described above but lack the ability for sustained transmission among humans. As such, continued evaluation of novel and emerging influenza viruses to monitor the acquisition of features that facilitate or enhance transmission in mammals represents an important component of risk assessment activities (Lipsitch et al. 2016). Assessments of virus transmissibility in the ferret model are typically conducted in two settings (Belser et al. 2016). In the most permissive setting, a serologically naive ferret is cohoused with an experimentally inoculated ferret; termed a direct contact model, this setup encompasses all potential modes of virus transmission but cannot distinguish between them if detected in the contact ferret. In a more stringent setting, a serologically naive ferret is placed in a separate cage to the experimentally inoculated ferret, prohibiting direct or indirect contact between the ferrets but permitting air exchange via perforations in the interface side wall between cages. Termed a respiratory droplet model, this setup measures virus transmissibility via respiratory droplets and droplet nuclei, although it does not provide information regarding the size of particles responsible for virus transmission to contact ferrets (Maines et al. 2006).

Seasonal, human-adapted influenza A viruses transmit efficiently among people, although the relative dominance of each transmission mode (direct contact, indirect contact, and airborne) is still poorly understood (Brankston et al. 2007). In contrast, the majority of documented, confirmed human infections with viruses of zoonotic origin are typically self-limiting and/or restricted to spread in small family clusters (Uyeki et al. 2017). Use of ferret transmission models largely support these observations in humans (Table 1), as meta-analyses have shown a correlation between secondary attack rates generated from either ferret or human data, with increased predictive power for data generated using a respiratory droplet transmission ferret model compared with a direct contact transmission model (Buhnerkempe et al. 2015). It should be noted that there is substantial variability between laboratory models used in the field evaluating virus transmissibility in ferrets, and these models do not fully recapitulate all transmission patterns observed in humans (Belser et al. 2018). Nonetheless, studies evaluating the transmission potential of a specific strain in ferrets, in tandem with other laboratory readouts, provide information critical toward understanding transmission dynamics in humans.

As influenza viruses continue to reassort and jump species barriers to cause human infection, it has become clear that, like pathogenicity, virus transmissibility can be notoriously difficult to predict based on genetic and antigenic analyses alone. Numerous host range barriers contribute toward the species specificity of influenza A viruses (Long et al. 2019). Broadly, most avianorigin influenza A viruses that are sporadically isolated from humans do not transmit well between ferrets (Table 1; Maines et al. 2006; Sutton 2018). In contrast, pandemic influenza viruses and well-adapted seasonal influenza viruses generally transmit efficiently by the airborne route in this model. As interspecies transmission of influenza A viruses continues to occur (Subbarao 2019), the pool of viruses warranting evaluation of transmissibility in ferrets continues to expand. The broad heterogeneity of viruses from zoonotic sources has challenged assumptions about the pandemic risk of viruses, endemic in different species. For example, numerous swineorigin $\mathrm{H} 1$ and $\mathrm{H} 3$ subtype variant viruses have shown enhanced transmissibility compared with avian-origin viruses in recent years (Sun et al. 2018; Pulit-Penaloza et al. 2019a).

There are several molecular determinants in both structural and nonstructural genes of influenza viruses that are believed to contribute to efficient transmission in humans (Belser et al. 2010). Although detailed analysis of these determinants lies outside the scope of this review, many of the molecular markers involved in influenza virus tropism, replication, and transmission that have been well-studied in the ferret model are located in the HA. Viruses that possess an HA with binding preference for $\alpha 2,6$ linked sialic acids, which is the receptor found in abundance in the human upper airways, generally show enhanced transmission compared with viruses that possess a binding preference 
for $\alpha 2,3$-linked sialic acids, which are more prevalent in the mammalian lower respiratory tract (Kumlin et al. 2008; de Graaf and Fouchier 2014). Recently, the ferret model was used to reveal that the mammalian soft palate may play a role in adaptation of transmissible viruses by enrichment of viruses that bind human-like receptors (Lakdawala et al. 2015). The acid stability of the influenza HA has also been implicated in virus host range, as the $\mathrm{pH}$ threshold for HA activation for most transmissible, human-adapted influenza viruses is lower ( $\mathrm{pH}$ of fusion 5.0-5.4) than many zoonotic influenza viruses ( $\mathrm{pH}$ of fusion $>5.4$ ) that lack the capacity for efficient mammalian transmission (Russell et al. 2018).

Beyond the HA, the polymerase protein PB2, at position 627, is well-known as a molecular determinant of mammalian pathogenicity and host range (Subbarao et al. 1993). Viruses bearing the avian consensus residue (glutamic acid) at this position or lack compensatory mutations generally display reduced transmission compared with viruses bearing a lysine, indicating a role for this residue in transmission modulation as well (Steel et al. 2009; Van Hoeven et al. 2009). Adaptations that contribute to enhanced influenza virus transmissibility encompass nearly all features of the virus, with roles for most of these studied in the ferret model, including but not limited to the functional balance between viral HA and neuraminidase (NA) (Zanin et al. 2015), the length of the NA stalk (Blumenkrantz et al. 2013), and the contribution of nonstructural protein 1 (NS1) in viral replication and pathology in the upper respiratory tract (Zanin et al. 2017). Host innate immune responses also contribute to host range, as transmissible human influenza viruses have been found to elicit higher levels of proinflammatory cytokines, associated with sneezing and rhinorrhea, compared with avian influenza viruses that do not transmit between ferrets (Maines et al. 2012). These represent just some of the key host and viral determinants that have been identified to modulate influenza A virus transmissibility (reviewed in detail in Long et al. 2019).

Beyond virus-specific properties, it is critical to consider that the transmission potential of an influenza virus represents a multifactorial trait, encompassing complex dynamics between the host, recipient, and environment. Properties of the host (including both genetic determinants and specific immunological history) can influence susceptibility to influenza virus infection; use of pharmaceutical and/or nonpharmaceutical interventions can also modulate virus transmissibility (Belser et al. 2010). However, regardless of this variability, transmission to and infection of susceptible contacts largely takes place following release of infectious, airborne particles into the environment from an infected host, underscoring the need to closely examine the properties of influenza viruses in aerosols. As such, recent studies in the ferret model have sought to examine virus transmissibility not only from the standpoint of an infected animal, but to additionally include investigation of the generation, expulsion, and stability of influenza viruses once they are shed from an infected host (Gustin et al. 2012), as will be discussed below.

Routine ferret transmission experiments are typically conducted to determine virus transmission efficiency during continuous exposure to an infected donor, making it difficult to quantify the amount of virus to which the contact ferret is exposed. However, the duration and timing of virus exposure play an important role in influenza transmission between mammals. Transmission efficiency between ferrets has been shown to increase with the length of exposure to the donor ferret and is most efficient before the onset of clinical symptoms (Roberts et al. 2012). Naive ferrets exposed to air from donor ferrets shortly after inoculation are more likely to become productively infected than ferrets exposed to donors later during infection despite high levels of virus detected in the air released by the donor ferrets (Koster et al. 2012; Roberts et al. 2012; Zhou et al. 2018). Because of the lack of efficient methods for collection and quantification of exhaled infectious influenza virus from ferrets, it is not clear whether this phenomenon is related to lower loads of infectious virus in aerosols and whether host factors contribute to this decrease in transmission. 
J.A. Belser et al.

\section{FERRET PATHOGENICITY AND TRANSMISSIBILITY IN THE CONTEXT OF AEROBIOLOGY}

Initial evaluations of influenza virus pathogenicity and transmissibility in the context of risk assessment activities measure the capacity of a virus to cause a productive infection in an experimentally inoculated ferret, determine the relative severity of disease resulting from this infection, and assess if serologically naive ferrets placed in contact with inoculated ferrets (either in the presence of direct contact or via exchange of air only) become productively infected. However, these studies provide an incomplete picture of the transmission dynamics between mammals. Experimental infection of ferrets in the laboratory is routinely performed by instillation of a high dose of liquid inoculum administered to the nares of the animal (intranasal route), which delivers a high dose of virus to the respiratory tract and typically results in robust replication and peak viral titers observed within 48 hours postinoculation. To better emulate how humans are exposed to and infected by influenza virus, recent efforts have sought to expose ferrets to aerosolized influenza virus. Inhalation exposure systems require precise, real-time monitoring and control of numerous parameters including air flow, pressure, temperature, and humidity (Roy and Pitt 2012), control of which may be facilitated with automated platforms (Hartings and Roy 2004). Inhalation of virusladen aerosols at low, physiologically relevant doses can lead to robust infection of ferrets, with kinetics, duration, and magnitude of virulence and transmission more similar to natural, airborne influenza virus infection than following traditional high-dose intranasal inoculation methods (Gustin et al. 2011). This inoculation method may be performed via either nose-only or whole-body inhalation exposure systems, with or without anesthesia of ferrets during the exposure (Lednicky et al. 2010; Gustin et al. 2011; MacInnes et al. 2011).

Aerosolized virus is released from humans infected with influenza virus following normal breathing, talking, coughing, and sneezing (Thomas 2013). There are numerous established methods and air sampling devices to investigate aerosolized influenza virus, each with their advantages and disadvantages depending on the sampling environment and research questions being investigated (Verreault et al. 2008). The more effective and straightforward methods of bioaerosol collection use cyclone samplers, dry impactors, and filters that do not preserve virus viability and are limited to quantification of viral genetic material in the air. As these analyses do not measure infectious virus load in the air, they provide an incomplete picture of what is shed from infected individuals or animals. Methods based on collection of samples into aqueous media, using, for example, impingers or wet surface aerosol collectors, are a better alternative for quantification of infectious influenza virus (Lindsley et al. 2017). However, the success of quantifying aerosolized virus not only depends on the type of sampler but also on the collection time; typically, longer collection times will result in greater inactivation of virus, whereas shorter collection periods result in reduced recovery with greater variability in collected data (Koster et al. 2012). For these reasons, efforts to quantify aerosolized virus shed from inoculated ferrets have typically measured the size distribution of particles (via a particle spectrometer) and/or the relative viral genome load within these particles (via a sampling device) (Cao et al. 2011). More rarely, assessments of infectious virus have been determined using gel-based multistage viable cascade impactors (Gustin et al. 2011) showing that not only can infectious virus be shed from inoculated ferrets, but that transmission is mediated by virus-laden aerosols in the respirable range (Gustin et al. 2011; Zhou et al. 2018).

Experimental data suggest that productive infection of humans and ferrets can be initiated by exposure to low doses of influenza virus. The $50 \%$ infectious dose for human infection by $\mathrm{H} 2 \mathrm{~N} 2$ virus was shown to be three TCID $_{50}$ (Alford et al. 1966), whereas five or less infectious particles of human, avian, and swine viruses were sufficient to infect $>50 \%$ of ferrets in a laboratory setting (Gustin et al. 2011; PulitPenaloza et al. 2019b). Even though influenza virus stability in aerosols may decrease over time, the resulting low doses of virus are none- 
theless capable of causing productive infections, underscoring the contribution that aerobiological measurements can make in our understanding of transmission dynamics and transmission potential of novel influenza viruses. Furthermore, ferrets inoculated with transmissible influenza viruses may expel more aerosols, with an increased viral load, compared with ferrets inoculated with nontransmissible influenza viruses (Gustin et al. 2013), a phenomenon likely dependent on virus gene constellation and other unidentified factors (Lakdawala et al. 2011; Zhou et al. 2018). That said, viral load in aerosols released from infected mammals is just one of numerous factors governing virus transmission from infected to susceptible contacts; other parameters include (but are not limited to) replication efficiency of the virus, host immune responses, and the size distribution of released particles (Koster et al. 2012; Zhou et al. 2018).

Virus-laden aerosols are subjected to a range of environmental conditions and dynamics that can ultimately modulate their infectivity to a susceptible host (Weber and Stilianakis 2008; Marr et al. 2019). Environmental conditions (specifically humidity and temperature) can affect not only the size distribution of exhaled aerosols, but also the levels of infectious virus present in exhalations and the frequency of virus transmission between ferrets (Gustin et al. 2015). Viruses capable of efficient transmission between ferrets may show higher stability in aerosols and remain infectious for prolonged periods of time in the air despite particle settling and inactivation (Pulit-Penaloza et al. 2019b). Beyond virus-specific properties, the presence of mucins in virus-containing respiratory droplets expelled from infected humans likely contributes to infectivity in an aerosol state (Kormuth et al. 2018). It is important to remember that these properties may contribute to virus infectivity in a strain-specific manner, as stability in aerosols may vary greatly between viruses (Pulit-Penaloza et al. 2019b).

Effective pandemic risk modeling of influenza virus transmission using the ferret model requires in-depth understanding of the ability of novel and emerging viruses to transmit through the air. Elucidating host and/or virus factors that affect virus aerosolization, stability following aerosolization, and infectious dose required to initiate productive infection in a susceptible host are important for both predicting the potential of transmission in the human population and development of pandemic countermeasures. There is a need for development and continued refinement of current methods to facilitate increased inclusion in routine laboratory experimentation, especially those that allow extended collection times while preserving virus viability.

\section{MOVING FORWARD}

Experimental inoculation of ferrets with influenza virus represents one facet of an expansive laboratory toolkit (inclusive but not limited to in vivo, ex vivo, genetic, and antigenic analyses) to study virus pathogenicity, transmissibility, and tropism. The closer our in vivo models emulate human influenza virus infections, the more applicable data generated from these models will be toward public health efforts. There is a need to continuously evaluate how ferrets are used in influenza virus research and risk assessment settings and, when possible, identify ways in which these models can be improved.

The studies described in this review have all focused on respiratory exposure routes, as influenza virus is primarily a respiratory pathogen in humans, and inhalation of virus particles is likely a dominant route of virus transmission. However, as has been described above, virus pathogenicity and transmissibility profiles can be modulated depending on the specific conditions associated with this respiratory exposure. Importantly, nonrespiratory exposure routes can lead to productive virus infection in ferrets, with a similar dynamic range of infection kinetics depending on the route, dose, and strain used to infect (Belser et al. 2016). Although it is likely that these nonrespiratory inoculation routes (including but not limited to ocular and gastrointestinal exposures) represent a relatively lower proportion of human infections compared with respiratory exposure, their study nonetheless contributes to our understanding of the capacity of influenza viruses to cause disease and transmit among mammals. As such, it is impor- 
J.A. Belser et al.

tant to ensure that our in vivo models capture and emulate all potential ways in which humans are exposed to influenza virus, regardless of the relative dominance of any one particular route.

It should be noted that the studies mentioned in this review describe virus infection of young, healthy ferrets that are immunologically naive to influenza virus. The use of seronegative ferrets is a critical component of risk-assessment evaluations of novel and emerging influenza viruses, as these first-line investigations focus primarily on the pathogenicity and transmissibility of the individual virus strain being tested (Belser et al. 2018). That said, it is known that prior exposure(s) to influenza virus (achieved by either prior infection, vaccination, or both) can shape the resulting host response to the infection (Laurie et al. 2010; Pearce et al. 2012a; Kirchenbaum et al. 2016). Furthermore, altered health states of the host (including age, pregnancy, and immunosuppression) are known to greatly influence the duration of virus shedding, disease progression, and emergence of antiviral resistance and have been modeled in ferrets $(\mathrm{Pa}$ quette et al. 2014; Roosenhoff et al. 2018; Yoon et al. 2018). Increased attention to the role the host microbiome plays in infection is similarly understudied in the ferret model. It is likely that use of ferrets to model and understand complex virus-host interactions and immune responses to infection will increase in the future, especially as laboratory reagents and tools become increasingly commercially available.

Recent advances in aerobiology and aerovirology, as discussed above, have greatly improved our understanding of the capacity of human and zoonotic influenza viruses to infect and cause disease in mammals. These fields represent just one of a number of areas for which technological improvements have contributed toward enhanced study of influenza viruses using the ferret model. Development of bioluminescent and fluorescent influenza A reporter viruses has permitted examination of viral replication kinetics in real time (Karlsson et al. 2015; Spronken et al. 2015). Molecular tagging of influenza viruses has provided insight into selection of quasispecies within an infected host and bottleneck dynamics during transmission to susceptible contacts (Varble et al. 2014; Frise et al. 2016), identifying differences in transmission dynamics between contact and respiratory droplet models. Similarly, next-generation sequencing of samples at both the within-host and between-host scales has provided an increased understanding of the role minor variant populations can contribute to these dynamics (Lin et al. 2014; Varble et al. 2014). As our molecular toolkit improves, so will the ability of virus-infected ferrets to provide insight into the dynamics of human influenza virus infections.

\section{CONCLUDING REMARKS}

The continued diversity of influenza A viruses jumping species barriers to cause documented human infections, coupled with increased surveillance efforts worldwide that have identified the heterogeneity of viruses in zoonotic reservoirs, has underscored the continued need to monitor and evaluate these viruses in laboratory models. Ferrets have represented a critical in vivo model for these activities, and it is likely that the role this species plays in our understanding of influenza virus pathogenicity, transmissibility, and tropism will only increase in the coming years. Advances in cell culture models have sought to more closely emulate the complexity of in vivo models; examples include the development of physiologically relevant inoculation routes and the generation of organoid tissues that are representative of the human respiratory tract (Creager et al. 2017; Hui et al. 2018). Similarly, ex vivo primary differentiated cultures of ferret tissue-specific cells provide an additional link between in vivo and in vitro experimentation, supporting and enhancing studies investigating viral pathogenicity and tropism (Zeng et al. 2013, 2019). However, because of the dynamic virus-host responses that are inherent following mammalian infection with influenza virus, these cell culture models may approach the complexity of in vivo experimentation but will not replace the need for in vivo models.

Frequently using in vitro-generated data, mathematical models can elucidate complex features of infection dynamics between influenza viruses and host cells and/or interactions be- 
tween other pathogens (Beauchemin and Handel 2011; Smith 2018). In recent years, in efforts to reduce the total number of ferrets used in influenza virus research and to collect as much meaningful information as possible from historical data, meta-analyses of data generated from ferrets have been conducted to examine in more detail a range of dynamic replication and transmission properties of influenza viruses (Stark et al. 2013; Buhnerkempe et al. 2015). As studies using mathematical models have provided insight into influenza virus infection in vivo (Pawelek et al. 2016) and can contribute to refinement of experimental conditions used in laboratory mammalian models (Handel et al. 2018), increased collaborative efforts to glean additional information from measures of influenza virus pathogenicity and transmissibility in the ferret model are warranted.

As influenza viruses continue to emerge from zoonotic reservoirs, laboratory investigations to understand the public health risk posed by these viruses are of paramount importance. The studies discussed in this review highlight both the importance of the ferret model for ongoing risk assessment and research activities and the applicability of data generated in the ferret model toward understanding human infection and disease.

\section{ACKNOWLEDGMENTS}

The findings and conclusions in this review are those of the authors and do not necessarily reflect the official position of the Centers for Disease Control and Prevention or the Agency for Toxic Substances and Disease Registry.

This article has been made freely available online courtesy of TAUNS Laboratories.

\section{REFERENCES}

Alford RH, Kasel JA, Gerone PJ, Knight V. 1966. Human influenza resulting from aerosol inhalation. Proc Soc Exp BiolMed 122: 800-804. doi:10.3181/00379727-122-31255

Barman S, Krylov PS, Fabrizio TP, Franks J, Turner JC, Seiler P, Wang D, Rehg JE, Erickson GA, Gramer M, et al. 2012. Pathogenicity and transmissibility of North American triple reassortant swine influenza A viruses in ferrets. PLoS Pathog 8: e1002791. doi:10.1371/journal .ppat.1002791
Influenza Virulence and Transmissibility in Ferrets

Baz M, Paskel M, Matsuoka Y, Zengel J, Cheng X, Jin H, Subbarao K. 2013. Replication and immunogenicity of swine, equine, and avian $\mathrm{H} 3$ subtype influenza viruses in mice and ferrets. J Virol 87: 6901-6910. doi:10.1128/ JVI.03520-12

Beauchemin CA, Handel A. 2011. A review of mathematical models of influenza A infections within a host or cell culture: lessons learned and challenges ahead. BMC Public Health 11: S7. doi:10.1186/1471-2458-11-S1-S7

Belser JA, Tumpey TM. 2014. Mammalian models for the study of $\mathrm{H} 7$ virus pathogenesis and transmission. Curr Top Microbiol Immunol 385: 275-305.

Belser JA, Lu X, Maines TR, Smith C, Li Y, Donis RO, Katz JM, Tumpey TM. 2007. Pathogenesis of avian influenza (H7) virus infection in mice and ferrets: enhanced virulence of Eurasian H7N7 viruses isolated from humans. $J$ Virol 81: 11139-11147. doi:10.1128/JVI.01235-07

Belser JA, Maines TR, Tumpey TM, Katz JM. 2010. Influenza A virus transmission: contributing factors and clinical implications. Expert Rev Mol Med 12: e39. doi:10.1017/ S1462399410001705

Belser JA, Katz JM, Tumpey TM. 2011. The ferret as a model organism to study influenza A virus infection. Dis Model Mech 4: 575-579. doi:10.1242/dmm.007823

Belser JA, Gustin KM, Pearce MB, Maines TR, Zeng H, Pappas C, Sun X, Carney PJ, Villanueva JM, Stevens J, et al. 2013. Pathogenesis and transmission of avian influenza A (H7N9) virus in ferrets and mice. Nature 501: 556-559. doi:10.1038/nature12391

Belser JA, Eckert AM, Tumpey TM, Maines TR. 2016. Complexities in ferret influenza virus pathogenesis and transmission models. Microbiol Mol Biol Rev 80: 733-744. doi:10.1128/MMBR.00022-16

Belser JA, Pulit-Penaloza JA, Sun X, Brock N, Pappas C, Creager HM, Zeng H, Tumpey TM, Maines TR. 2017. A novel A(H7N2) influenza virus isolated from a veterinarian caring for cats in a New York City animal shelter causes mild disease and transmits poorly in the ferret model. J Virol 91: e00672-17. doi:10.1128/JVI.00672-17

Belser JA, Barclay W, Barr I, Fouchier RAM, Matsuyama R, Nishiura H, Peiris M, Russell CJ, Subbarao K, Zhu H, et al. 2018. Ferrets as models for influenza virus transmission studies and pandemic risk assessments. Emerg Infect Dis 24: 965-971. doi:10.3201/eid2406.172114

Blumenkrantz D, Roberts KL, Shelton H, Lycett S, Barclay WS. 2013. The short stalk length of highly pathogenic avian influenza H5N1 virus neuraminidase limits transmission of pandemic H1N1 virus in ferrets. J Virol 87: 10539-10551. doi:10.1128/JVI.00967-13

Brankston G, Gitterman L, Hirji Z, Lemieux C, Gardam M. 2007. Transmission of influenza A in human beings. Lancet Infect Dis 7: 257-265. doi:10.1016/S1473-3099(07) 70029-4

Buhnerkempe MG, Gostic K, Park M, Ahsan P, Belser JA, Lloyd-Smith JO. 2015. Mapping influenza transmission in the ferret model to transmission in humans. eLife 4: e07969. doi:10.7554/eLife.07969

Cao G, Noti JD, Blachere FM, Lindsley WG, Beezhold DH. 2011. Development of an improved methodology to detect infectious airborne influenza virus using the NIOSH bioaerosol sampler. J Environ Monit 13: 3321-3328. doi:10.1039/c1em10607d 
J.A. Belser et al.

Coates DM, Sweet C, Quarles JM, Overton HA, Smith H. 1985. Severity of fever in influenza: studies on the relation between viral surface antigens, pyrexia, level of nasal virus and inflammatory response in the ferret. J Gen Virol 66: 1627-1631. doi:10.1099/0022-1317-66-7-1627

Creager HM, Zeng H, Pulit-Penaloza JA, Maines TR, Tumpey TM, Belser JA. 2017. In vitro exposure system for study of aerosolized influenza virus. Virology 500: 62 70. doi:10.1016/j.virol.2016.10.007

de Graaf M, Fouchier RA. 2014. Role of receptor binding specificity in influenza A virus transmission and pathogenesis. EMBO J 33: 823-841. doi:10.1002/embj.2013 87442

de Wit E, Siegers JY, Cronin JM, Weatherman S, van den Brand JM, Leijten LM, van Run P, Begeman L, van den Ham HJ, Andeweg AC, et al. 2018. 1918 H1N1 influenza virus replicates and induces proinflammatory cytokine responses in extrarespiratory tissues of ferrets. J Infect Dis 217: 1237-1246. doi:10.1093/infdis/jiy003

DiPiazza A, Richards K, Batarse F, Lockard L, Zeng H, García-Sastre A, Albrecht RA, Sant AJ. 2016. Flow cytometric and cytokine ELISpot approaches to characterize the cellmediated immune response in ferrets following influenza virus infection. J Virol 90: 7991-8004. doi:10.1128/JVI $.01001-16$

Enkirch T, von Messling V. 2015. Ferret models of viral pathogenesis. Virology 479-480: 259-270. doi:10.1016/j virol.2015.03.017

Frise R, Bradley K, van Doremalen N, Galiano M, Elderfield RA, Stilwell P, Ashcroft JW, Fernandez-Alonso M, Miah S, Lackenby A, et al. 2016. Contact transmission of influenza virus between ferrets imposes a looser bottleneck than respiratory droplet transmission allowing propagation of antiviral resistance. Sci Rep 6: 29793. doi:10.1038/ srep29793

Gustin KM, Belser JA, Wadford DA, Pearce MB, Katz JM, Tumpey TM, Maines TR. 2011. Influenza virus aerosol exposure and analytical system for ferrets. Proc Natl Acad Sci 108: 8432-8437. doi:10.1073/pnas.1100768108

Gustin KM, Belser JA, Katz JM, Tumpey TM, Maines TR. 2012. Innovations in modeling influenza virus infections in the laboratory. Trends Microbiol 20: 275-281. doi:10 $.1016 /$ j.tim.2012.03.006

Gustin KM, Katz JM, Tumpey TM, Maines TR. 2013. Comparison of the levels of infectious virus in respirable aerosols exhaled by ferrets infected with influenza viruses exhibiting diverse transmissibility phenotypes. J Virol 87: 7864-7873. doi:10.1128/JVI.00719-13

Gustin KM, Belser JA, Veguilla V, Zeng H, Katz JM, Tumpey TM, Maines TR. 2015. Environmental conditions affect exhalation of $\mathrm{H} 3 \mathrm{~N} 2$ seasonal and variant influenza viruses and respiratory droplet transmission in ferrets. PLoS ONE 10: e0125874. doi:10.1371/journal.pone. 0125874

Hamid S, Arima Y, Dueger E, Konings F, Bell L, Lee C-K, Luo D, Otsu S, Olowokure B, Li A, et al. 2018. From H5N1 to $\mathrm{HxNy}$ : an epidemiologic overview of human infections with avian influenza in the Western Pacific Region, 2003-2017. Western Pac Surveill Response J 9: 1-15. doi:10.5365/wpsar.2018.9.2.001

Handel A, Li Y, McKay B, Pawelek KA, Zarnitsyna V, Antia R. 2018. Exploring the impact of inoculum dose on host immunity and morbidity to inform model-based vaccine design. PLoS Comput Biol 14: e1006505. doi:10.1371/jour nal.pcbi.1006505

Hartings JM, Roy CJ. 2004. The automated bioaerosol exposure system: Preclinical platform development and a respiratory dosimetry application with nonhuman primates. J Pharmacol Toxicol Methods 49: 39-55. doi:10 $.1016 /$ j.vascn.2003.07.001

Huang SS, Banner D, Fang Y, Ng DC, Kanagasabai T, Kelvin DJ, Kelvin AA. 2011. Comparative analyses of pandemic $\mathrm{H} 1 \mathrm{~N} 1$ and seasonal H1N1, H3N2, and influenza B infections depict distinct clinical pictures in ferrets. PLOS ONE 6: e27512. doi:10.1371/journal.pone.0027512

Hui KPY, Ching RHH, Chan SKH, Nicholls JM, Sachs N, Clevers H, Peiris JSM, Chan MCW. 2018. Tropism, replication competence, and innate immune responses of influenza virus: an analysis of human airway organoids and ex-vivo bronchus cultures. Lancet Respir Med 6: 846854. doi:10.1016/S2213-2600(18)30236-4

Imai M, Watanabe T, Kiso M, Nakajima N, Yamayoshi S, Iwatsuki-Horimoto K, Hatta M, Yamada S, Ito M, SakaiTagawa Y, et al. 2017. A highly pathogenic avian H7N9 influenza virus isolated from a human is lethal in some ferrets infected via respiratory droplets. Cell Host Microbe 22: 615-626.e8. doi:10.1016/j.chom.2017.09.008

Itoh Y, Shinya K, Kiso M, Watanabe T, Sakoda Y, Hatta M, Muramoto Y, Tamura D, Sakai-Tagawa Y, Noda T, et al 2009. In vitro and in vivo characterization of new swineorigin H1N1 influenza viruses. Nature 460: 1021-1025. doi:10.1038/nature08260

Iuliano AD, Roguski KM, Chang HH, Muscatello DJ, Palekar R, Tempia S, Cohen C, Gran JM, Schanzer D, Cowling $\mathrm{BJ}$, et al. 2018. Estimates of global seasonal influenzaassociated respiratory mortality: a modelling study. Lancet 391: 1285-1300. doi:10.1016/S0140-6736(17)33293-2

Jayaraman A, Chandrasekaran A, Viswanathan K, Raman R, Fox JG, Sasisekharan R. 2012. Decoding the distribution of glycan receptors for human-adapted influenza A viruses in ferret respiratory tract. PLoS ONE 7: e27517. doi:10 .1371/journal.pone.0027517

Jia N, Barclay WS, Roberts K, Yen HL, Chan RW, Lam AK, Air G, Peiris JS, Dell A, Nicholls JM, et al. 2014. Glycomic characterization of respiratory tract tissues of ferrets: implications for its use in influenza virus infection studies. J Biol Chem 289: 28489-28504. doi:10.1074/jbc.M114 .588541

Jones JC, Baranovich T, Marathe BM, Danner AF, Seiler JP, Franks J, Govorkova EA, Krauss S, Webster RG. 2014. Risk assessment of $\mathrm{H} 2 \mathrm{~N} 2$ influenza viruses from the avian reservoir. J Virol 88: 1175-1188. doi:10.1128/JVI.02526-13

Karlsson EA, Meliopoulos VA, Savage C, Livingston B, Mehle A, Schultz-Cherry S. 2015. Visualizing real-time influenza virus infection, transmission and protection in ferrets. Nat Commun 6: 6378. doi:10.1038/ncomms7378

Kirchenbaum GA, Ross TM. 2017. Generation of monoclonal antibodies against immunoglobulin proteins of the domestic ferret (Mustela putorius furo). J Immunol Res 2017: 5874572. doi:10.1155/2017/5874572

Kirchenbaum GA, Carter DM, Ross TM. 2016. Sequential infection in ferrets with antigenically distinct seasonal H1N1 influenza viruses boosts hemagglutinin stalk-specific antibodies. J Virol 90: 1116-1128. doi:10.1128/JVI $.02372-15$ 
Kormuth KA, Lin K, Prussin AJ II, Vejerano EP, Tiwari AJ, Cox SS, Myerburg MM, Lakdawala SS, Marr LC. 2018. Influenza virus infectivity is retained in aerosols and droplets independent of relative humidity. J Infect Dis 218: 739-747. doi:10.1093/infdis/jiy221

Koster F, Gouveia K, Zhou Y, Lowery K, Russell R, MacInnes H, Pollock Z, Layton RC, Cromwell J, Toleno D, et al. 2012. Exhaled aerosol transmission of pandemic and seasonal H1N1 influenza viruses in the ferret. PLoS ONE 7: e33118. doi:10.1371/journal.pone.0033118

Krammer F, Smith GJD, Fouchier RAM, Peiris M, Kedzierska K, Doherty PC, Palese P, Shaw ML, Treanor J, Webster RG, et al. 2018. Influenza. Nat Rev Dis Primers 4: 3. doi:10 .1038/s41572-018-0002-y

Kuiken T, van den Brand J, van Riel D, Pantin-Jackwood M, Swayne DE. 2010. Comparative pathology of select agent influenza A virus infections. Vet Pathol 47: 893-914. doi:10.1177/0300985810378651

Kumlin U, Olofsson S, Dimock K, Arnberg N. 2008. Sialic acid tissue distribution and influenza virus tropism. Influenza Other Respir Viruses 2: 147-154. doi:10.1111/j .1750-2659.2008.00051.x

Lakdawala SS, Lamirande EW, Suguitan AL Jr, Wang W, Santos CP, Vogel L, Matsuoka Y, Lindsley WG, Jin H, Subbarao K. 2011. Eurasian-origin gene segments contribute to the transmissibility, aerosol release, and morphology of the 2009 pandemic H1N1 influenza virus. PLoS Pathog 7: e1002443. doi:10.1371/journal.ppat.1002443

Lakdawala SS, Jayaraman A, Halpin RA, Lamirande EW, Shih AR, Stockwell TB, Lin X, Simenauer A, Hanson CT, Vogel L, et al. 2015. The soft palate is an important site of adaptation for transmissible influenza viruses. $\mathrm{Na}$ ture 526: 122-125. doi:10.1038/nature15379

Laurie KL, Carolan LA, Middleton D, Lowther S, Kelso A, Barr IG. 2010. Multiple infections with seasonal influenza $\mathrm{A}$ virus induce cross-protective immunity against $\mathrm{A}$ (H1N1) pandemic influenza virus in a ferret model. $J$ Infect Dis 202: 1011-1020. doi:10.1086/656188

Lednicky JA, Hamilton SB, Tuttle RS, Sosna WA, Daniels DE, Swayne DE. 2010. Ferrets develop fatal influenza after inhaling small particle aerosols of highly pathogenic avian influenza virus A/Vietnam/1203/2004 (H5N1). Virol J 7: 231. doi:10.1186/1743-422X-7-231

Lee IW, Kim YI, Lim GJ, Kwon HI, Si YJ, Park SJ, Kim EH, Kim SM, Nguyen HD, Song MS, et al. 2018. Comparison of the virulence and transmissibility of canine $\mathrm{H} 3 \mathrm{~N} 2$ in fluenza viruses and characterization of their canine adaptation factors. Emerg Microbes Infect 7: 17.

Lin Z, Farooqui A, Li G, Wong GK, Mason AL, Banner D, Kelvin AA, Kelvin DJ, Leon AJ. 2014. Next-generation sequencing and bioinformatic approaches to detect and analyze influenza virus in ferrets. J Infect Dev Ctries 8: 498-509. doi:10.3855/jidc.3749

Lindsley WG, Green BJ, Blanchere FM, Martin SB, Law BF, Jensen PA, Schafer MP. 2017. Sampling and characterization of bioaerosols. In NIOSH manual of analytical methods (NMAM), 5th ed. (ed. NIOSH), pp. BA-2-BA104. U.S. Department of Health \& Human Services, Washington, DC.

Lipsitch M, Barclay W, Raman R, Russell CJ, Belser JA, Cobey S, Kasson PM, Lloyd-Smith JO, Maurer-Stroh S,
Influenza Virulence and Transmissibility in Ferrets

Riley S, et al. 2016. Viral factors in influenza pandemic risk assessment. eLife 5: e18491. doi:10.7554/eLife.18491

Long JS, Mistry B, Haslam SM, Barclay WS. 2019. Host and viral determinants of influenza A virus species specificity. Nat Rev Microbiol 17: 67-81. doi:10.1038/s41579-0180115-z

Lycett SJ, Duchatel F, Digard P. 2019. A brief history of bird flu. Philos Trans R Soc Lond B Biol Sci 374: 20180257. doi:10.1098/rstb.2018.0257

MacInnes H, Zhou Y, Gouveia K, Cromwell J, Lowery K, Layton RC, Zubelewicz M, Sampath R, Hofstadler S, Liu $\mathrm{Y}$, et al. 2011. Transmission of aerosolized seasonal H1N1 influenza A to ferrets. PLoS ONE 6: e24448. doi:10.1371/ journal.pone.0024448

Maines TR, Lu XH, Erb SM, Edwards L, Guarner J, Greer PW, Nguyen DC, Szretter KJ, Chen LM, Thawatsupha P. et al. 2005. Avian influenza (H5N1) viruses isolated from humans in Asia in 2004 exhibit increased virulence in mammals. J Virol 79: 11788-11800. doi:10.1128/JVI.79 .18.11788-11800.2005

Maines TR, Chen LM, Matsuoka Y, Chen H, Rowe T, Ortin J, Falcón A, Hien NT, Mai LQ, Sedyaningsih ER, et al. 2006. Lack of transmission of H5N1 avian-human reassortant influenza viruses in a ferret model. Proc Natl Acad Sci 103: 12121-12126. doi:10.1073/pnas.0605134103

Maines TR, Jayaraman A, Belser JA, Wadford DA, Pappas C, Zeng H, Gustin KM, Pearce MB, Viswanathan K, Shriver $\mathrm{ZH}$, et al. 2009. Transmission and pathogenesis of swineorigin $2009 \mathrm{~A}(\mathrm{H} 1 \mathrm{~N} 1)$ influenza viruses in ferrets and mice. Science 325: 484-487. doi:10.1126/science.1177238

Maines TR, Belser JA, Gustin KM, van Hoeven N, Zeng H, Svitek N, von Messling V, Katz JM, Tumpey TM. 2012. Local innate immune responses and influenza virus transmission and virulence in ferrets. J Infect Dis 205: 474-485. doi:10.1093/infdis/jir768

Margine I, Krammer F. 2014. Animal models for influenza viruses: Implications for universal vaccine development. Pathogens 3: 845-874. doi:10.3390/pathogens3040845

Marr LC, Tang JW, Van Mullekom J, Lakdawala SS. 2019. Mechanistic insights into the effect of humidity on airborne influenza virus survival, transmission and incidence. J R Soc Interface 16: 20180298. doi:10.1098/rsif .2018 .0298

Morens DM, Taubenberger JK. 2011. Pandemic influenza: certain uncertainties. Rev Med Virol 21: 262-284.

Munster VJ, de Wit E, van den Brand JM, Herfst S, Schrauwen EJ, Bestebroer TM, van de Vijver D, Boucher CA, Koopmans M, Rimmelzwaan GF, et al. 2009. Pathogenesis and transmission of swine-origin $2009 \mathrm{~A}(\mathrm{H} 1 \mathrm{N1})$ influenza virus in ferrets. Science 325: 481-483. doi:10 $.1126 /$ science. 1177127

Music N, Reber AJ, Kim JH, York IA. 2016. Peripheral leukocyte migration in ferrets in response to infection with seasonal influenza virus. PLoS ONE 11: e0157903. doi:10 .1371/journal.pone. 0157903

Ng PS, Böhm R, Hartley-Tassell LE, Steen JA, Wang H, Lukowski SW, Hawthorne PL, Trezise AE, Coloe PJ, Grimmond SM, et al. 2014. Ferrets exclusively synthesize Neu5Ac and express naturally humanized influenza A virus receptors. Nat Commun 5: 5750. doi:10.1038/ ncomms6750 
J.A. Belser et al.

OIE. 2015. Manual of diagnostic tests and vaccines for terrestrial animals. OIE Publications, Paris.

Pappas C, Yang H, Carney PJ, Pearce MB, Katz JM, Stevens J, Tumpey TM. 2015. Assessment of transmission, pathogenesis and adaptation of $\mathrm{H} 2$ subtype influenza viruses in ferrets. Virology 477: 61-71. doi:10.1016/j.virol.2015.01.002

Paquette SG, Huang SSH, Banner D, Xu L, León A, Kelvin AA Kelvin DJ. 2014. Impaired heterologous immunity in aged ferrets during sequential influenza A H1N1 infection. Virology 464-465: 177-183. doi:10.1016/j.virol.2014.07.013

Pawelek KA, Dor D Jr, Salmeron C, Handel A. 2016. Withinhost models of high and low pathogenic influenza virus infections: the role of macrophages. PLOS ONE 11: e0150568. doi:10.1371/journal.pone.0150568

Pearce MB, Belser JA, Gustin KM, Pappas C, Houser KV, Sun X, Maines TR, Pantin-Jackwood MJ, Katz JM, Tumpey TM. 2012a. Seasonal trivalent inactivated influenza vaccine protects against 1918 Spanish influenza virus infection in ferrets. J Virol 86: 7118-7125. doi:10.1128/JVI .00674-12

Pearce MB, Jayaraman A, Pappas C, Belser JA, Zeng H, Gustin KM, Maines TR, Sun X, Raman R, Cox NJ, et al. 2012b. Pathogenesis and transmission of swine origin A (H3N2)v influenza viruses in ferrets. Proc Natl Acad Sci 109: 3944-3949. doi:10.1073/pnas.1119945109

Pearce MB, Pappas C, Gustin KM, Davis CT, Pantin-Jackwood MJ, Swayne DE, Maines TR, Belser JA, Tumpey TM. 2017. Enhanced virulence of clade 2.3.2.1 highly pathogenic avian influenza A $\mathrm{H} 5 \mathrm{~N} 1$ viruses in ferrets. Virology 502: 114-122. doi:10.1016/j.virol.2016.12.024

Peng X, Alföldi J, Gori K, Eisfeld AJ, Tyler SR, Tisoncik-Go J, Brawand D, Law GL, Skunca N, Hatta M, et al. 2014. The draft genome sequence of the ferret (Mustela putorius furo) facilitates study of human respiratory disease. Nat Biotechnol 32: 1250-1255. doi:10.1038/nbt.3079

Pulit-Penaloza JA, Sun X, Creager HM, Zeng H, Belser JA, Maines TR, Tumpey TM. 2015. Pathogenesis and transmission of novel highly pathogenic avian influenza H5N2 and H5N8 viruses in ferrets and mice. J Virol 89: 1028610293. doi:10.1128/JVI.01438-15

Pulit-Penaloza JA, Simpson N, Yang H, Creager HM, Jones J, Carney P, Belser JA, Yang G, Chang J, Zeng H, et al. 2017. Assessment of molecular, antigenic, and pathological features of canine influenza $\mathrm{A}(\mathrm{H} 3 \mathrm{~N} 2)$ viruses that emerged in the United States. J Infect Dis 216: S499-S507. doi:10 .1093/infdis/jiw620

Pulit-Penaloza JA, Jones J, Sun X, Jang Y, Thor S, Belser JA, Zanders N, Creager HM, Ridenour C, Wang L, et al. 2018. Antigenically diverse swine origin $\mathrm{H} 1 \mathrm{~N} 1$ variant influenza viruses exhibit differential ferret pathogenesis and transmission phenotypes. J Virol 92: e00095.

Pulit-Penaloza JA, Belser JA, Tumpey TM, Maines TR. 2019a. Sowing the seeds of a pandemic? Mammalian pathogenicity and transmissibility of $\mathrm{H} 1$ variant influenza viruses from the swine reservoir. Trop Med Infect Dis 4: E41.

Pulit-Penaloza JA, Belser JA, Tumpey TM, Maines TR. 2019b. Swine-origin H1 influenza viruses isolated from humans exhibit sustained infectivity in an aerosol state. Appl Environ Microbiol 85: e00210-19.

Reber AJ, Music N, Kim JH, Gansebom S, Chen J, York I. 2018. Extensive T cell cross-reactivity between diverse seasonal influenza strains in the ferret model. Sci Rep 8: 6112. doi:10.1038/s41598-018-24394-Z

Reuman PD, Keely S, Schiff GM. 1989. Assessment of signs of influenza illness in the ferret model. J Virol Methods 24: 27-34. doi:10.1016/0166-0934(89)90004-9

Richard M, Schrauwen EJ, de Graaf M, Bestebroer TM, Spronken MI, van Boheemen S, de Meulder D, Lexmond P, Linster M, Herfst S, et al. 2013. Limited airborne transmission of H7N9 influenza A virus between ferrets. $\mathrm{Na}$ ture 501: 560-563. doi:10.1038/nature12476

Richard M, Herfst S, van den Brand JM, Lexmond P, Bestebroer TM, Rimmelzwaan GF, Koopmans M, Kuiken T, Fouchier RA. 2015. Low virulence and lack of airborne transmission of the Dutch highly pathogenic avian influenza virus H5N8 in ferrets. PLoS ONE 10: e0129827. doi:10.1371/journal.pone.0129827

Roberts KL, Shelton H, Stilwell P, Barclay WS. 2012. Transmission of a 2009 H1N1 pandemic influenza virus occurs before fever is detected, in the ferret model. PLOS ONE 7: e43303. doi:10.1371/journal.pone.0043303

Roosenhoff R, van der Vries E, van der Linden A, van Amerongen G, Stittelaar KJ, Smits SL, Schutten M, Fouchier RAM. 2018. Influenza A/H3N2 virus infection in immunocompromised ferrets and emergence of antiviral resistance. PLOS ONE 13: e0200849. doi:10.1371/journal.pone .0200849

Roy CJ, Pitt MLM. 2012. Infectious disease aerobiology: Aerosol challenge methods. In Biodefense research methodology and animal models (ed. Swearengen JR), pp. 6579. CRC, Boca Raton, FL.

Russell CJ, Hu M, Okda FA. 2018. Influenza hemagglutinin protein stability, activation, and pandemic risk. Trends Microbiol 26: 841-853. doi:10.1016/j.tim.2018.03.005

Schrauwen EJ, Herfst S, Leijten LM, van Run P, Bestebroer TM, Linster M, Bodewes R, Kreijtz JH, Rimmelzwaan GF, Osterhaus AD, et al. 2012. The multibasic cleavage site in $\mathrm{H} 5 \mathrm{~N} 1$ virus is critical for systemic spread along the olfactory and hematogenous routes in ferrets. J Virol 86: 39753984. doi:10.1128/JVI.06828-11

Shinya K, Ebina M, Yamada S, Ono M, Kasai N, Kawaoka Y. 2006. Avian flu: influenza virus receptors in the human airway. Nature 440: 435-436. doi:10.1038/440435a

Shope RE. 1934. The infection of ferrets with swine influenza virus. J Exp Med 60: 49-61. doi:10.1084/jem.60.1.49

Smith AM. 2018. Host-pathogen kinetics during influenza infection and coinfection: insights from predictive modeling. Immunol Rev 285: 97-112. doi:10.1111/imr.12692

Spronken MI, Short KR, Herfst S, Bestebroer TM, Vaes VP, van der Hoeven B, Koster AJ, Kremers GJ, Scott DP, Gultyaev AP, et al. 2015. Optimisations and challenges involved in the creation of various bioluminescent and fluorescent influenza A virus strains for in vitro and in vivo applications. PLoS ONE 10: e0133888. doi:10.1371/ journal.pone.0133888

Stark GV, Long JP, Ortiz DI, Gainey M, Carper BA, Feng J, Miller SM, Bigger JE, Vela EM. 2013. Clinical profiles associated with influenza disease in the ferret model. PLoS ONE 8: e58337. doi:10.1371/journal.pone.0058337

Steel J, Lowen AC, Mubareka S, Palese P. 2009. Transmission of influenza virus in a mammalian host is increased by PB2 amino acids $627 \mathrm{~K}$ or $627 \mathrm{E} / 701 \mathrm{~N}$. PLoS Pathog 5: e1000252. doi:10.1371/journal.ppat.1000252 
Subbarao K. 2019. The critical interspecies transmission barrier at the animal-human interface. Trop Med Infect Dis 4: E72.

Subbarao EK, London W, Murphy BR. 1993. A single amino acid in the PB2 gene of influenza A virus is a determinant of host range. J Virol 67: 1761-1764.

Sun X, Belser JA, Pulit-Penaloza JA, Zeng H, Lewis A, Shieh WJ, Tumpey TM, Maines TR. 2016. Pathogenesis and transmission assessments of two H7N8 influenza A viruses recently isolated from turkey farms in Indiana using mouse and ferret models. J Virol 90: 10936-10944. doi:10 .1128/JVI.01646-16

Sun X, Pulit-Penaloza JA, Belser JA, Pappas C, Pearce MB, Brock N, Zeng H, Creager HM, Zanders N, Jang Y, et al. 2018. Pathogenesis and transmission of genetically diverse swine-origin $\mathrm{H} 3 \mathrm{~N} 2$ variant influenza $A$ viruses from multiple lineages isolated in the United States, 2011-2016. J Virol 92: e00665.

Sutton TC. 2018. The pandemic threat of emerging H5 and H7 avian influenza viruses. Viruses 10: 461. doi:10.3390/ v10090461

Svitek N, Rudd PA, Obojes K, Pillet S, von Messling V. 2008. Severe seasonal influenza in ferrets correlates with reduced interferon and increased IL-6 induction. Virology 376: 53-59. doi:10.1016/j.virol.2008.02.035

Thomas RJ. 2013. Particle size and pathogenicity in the respiratory tract. Virulence 4: 847-858. doi:10.4161/viru .27172

Trock SC, Burke SA, Cox NJ. 2012. Development of an influenza virologic risk assessment tool. Avian Dis 56: 1058-1061. doi:10.1637/10204-041412-ResNote.1

Tumpey TM, Maines TR, Van Hoeven N, Glaser L, Solorzano A, Pappas C, Cox NJ, Swayne DE, Palese P, Katz JM, et al. 2007. A two-amino acid change in the hemagglutinin of the 1918 influenza virus abolishes transmission. Science 315: 655-659. doi:10.1126/science.1136212

Uyeki TM, Katz JM, Jernigan DB. 2017. Novel influenza A viruses and pandemic threats. Lancet 389: 2172-2174. doi:10.1016/S0140-6736(17)31274-6

Van Hoeven N, Pappas C, Belser JA, Maines TR, Zeng H, Garcia-Sastre A, Sasisekharan R, Katz JM, Tumpey TM. 2009. Human HA and polymerase subunit PB2 proteins confer transmission of an avian influenza virus through the air. Proc Natl Acad Sci 106: 3366-3371. doi:10.1073/ pnas.0813172106

van Riel D, Munster VJ, de Wit E, Rimmelzwaan GF, Fouchier RA, Osterhaus AD, Kuiken T. 2006. H5N1 virus attachment to lower respiratory tract. Science 312: 399. doi:10.1126/science.1125548

Varble A, Albrecht RA, Backes S, Crumiller M, Bouvier NM Sachs D, García-Sastre A, tenOever BR. 2014. Influenza A virus transmission bottlenecks are defined by infection route and recipient host. Cell Host Microbe 16: 691-700. doi:10.1016/j.chom.2014.09.020

Verreault D, Moineau S, Duchaine C. 2008. Methods for sampling of airborne viruses. Microbiol Mol Biol Rev 72: 413-444. doi:10.1128/MMBR.00002-08

Wan H, Sorrell EM, Song H, Hossain MJ, Ramirez-Nieto G, Monne I, Stevens J, Cattoli G, Capua I, Chen LM, et al. 2008. Replication and transmission of H9N2 influenza viruses in ferrets: evaluation of pandemic potential. PLoS ONE 3: e2923. doi:10.1371/journal.pone.0002923
Influenza Virulence and Transmissibility in Ferrets

Watanabe T, Kiso M, Fukuyama S, Nakajima N, Imai M, Yamada S, Murakami S, Yamayoshi S, Iwatsuki-Horimoto K, Sakoda Y, et al. 2013. Characterization of H7N9 influenza A viruses isolated from humans. Nature 501: 551-555. doi:10.1038/nature 12392

Weber TP, Stilianakis NI. 2008. Inactivation of influenza A viruses in the environment and modes of transmission: a critical review. J Infect 57: 361-373. doi:10.1016/j.jinf .2008.08.013

WHO. 2016. Tool for influenza pandemic risk assessment (TIPRA). WHO Press, Geneva.

Yen HL, Lipatov AS, Ilyushina NA, Govorkova EA, Franks J, Yilmaz N, Douglas A, Hay A, Krauss S, Rehg JE, et al. 2007. Inefficient transmission of H5N1 influenza viruses in a ferret contact model. J Virol 81: 6890-6898. doi:10 .1128/JVI.00170-07

Yen HL, Liang CH, Wu CY, Forrest HL, Ferguson A, Choy KT, Jones J, Wong DD, Cheung PP, Hsu CH, et al. 2011. Hemagglutinin-neuraminidase balance confers respiratory-droplet transmissibility of the pandemic H1N1 influenza virus in ferrets. Proc Natl Acad Sci 108: 1426414269. doi:10.1073/pnas.1111000108

Yoon SW, Wong SS, Zhu H, Chen R, Li L, Zhang Y, Guan Y, Webby RJ. 2018. Dysregulated T-helper type 1 (Th1):Th2 cytokine profile and poor immune response in pregnant ferrets infected with 2009 pandemic influenza $\mathrm{A}(\mathrm{H} 1 \mathrm{~N} 1)$ virus. J Infect Dis 217: 438-442. doi:10.1093/infdis/jix328

Zanin M, Marathe B, Wong SS, Yoon SW, Collin E, Oshansky C, Jones J, Hause B, Webby R. 2015. Pandemic swine $\mathrm{H} 1 \mathrm{~N} 1$ influenza viruses with almost undetectable neuraminidase activity are not transmitted via aerosols in ferrets and are inhibited by human mucus but not swine mucus. J Virol 89: 5935-5948. doi:10.1128/JVI.02537-14

Zanin M, Wong SS, Barman S, Kaewborisuth C, Vogel P, Rubrum A, Darnell D, Marinova-Petkova A, Krauss S, Webby RJ, et al. 2017. Molecular basis of mammalian transmissibility of avian $\mathrm{H} 1 \mathrm{~N} 1$ influenza viruses and their pandemic potential. Proc Natl Acad Sci 114: 1121711222. doi:10.1073/pnas.1713974114

Zeng H, Goldsmith CS, Maines TR, Belser JA, Gustin KM, Pekosz A, Zaki SR, Katz JM, Tumpey TM. 2013. Tropism and infectivity of influenza virus, including highly pathogenic avian $\mathrm{H} 5 \mathrm{~N} 1$ virus, in ferret tracheal differentiated primary epithelial cell cultures. J Virol 87: 2597-2607. doi:10.1128/JVI.02885-12

Zeng H, Goldsmith CS, Kumar A, Belser JA, Sun X, Pappas C, Brock N, Bai Y, Levine M, Tumpey TM, et al. 2019. Tropism and infectivity of a seasonal $\mathrm{A}(\mathrm{H} 1 \mathrm{~N} 1)$ and a highly pathogenic avian $\mathrm{A}(\mathrm{H} 5 \mathrm{~N} 1)$ influenza virus in primary differentiated ferret nasal epithelial cell cultures. $J$ Virol 93. doi:10.1128/JVI.00080-19

Zhou J, Wei J, Choy KT, Sia SF, Rowlands DK, Yu D, Wu CY, Lindsley WG, Cowling BJ, McDevitt J, et al. 2018. Defining the sizes of airborne particles that mediate influenza transmission in ferrets. Proc Natl Acad Sci 115: E2386E2392. doi:10.1073/pnas.1716771115

Zitzow LA, Rowe T, Morken T, Shieh WJ, Zaki S, Katz JM. 2002. Pathogenesis of avian influenza A (H5N1) viruses in ferrets. J Virol 76: 4420-4429. doi:10.1128/JVI.76.9 $.4420-4429.2002$ 


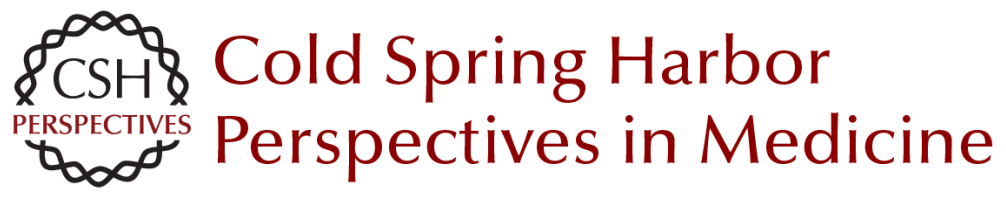

\title{
Ferreting Out Influenza Virus Pathogenicity and Transmissibility: Past and Future Risk Assessments in the Ferret Model
}

\author{
Jessica A. Belser, Joanna A. Pulit-Penaloza and Taronna R. Maines
}

Cold Spring Harb Perspect Med 2020; doi: 10.1101/cshperspect.a038323 originally published online December 23, 2019

\section{Subject Collection Influenza: The Cutting Edge}

\section{Emerging HxNy Influenza A Viruses William J. Liu, Yan Wu, Yuhai Bi, et al. \\ Equine Influenza Thomas M. Chambers \\ Human Influenza Epidemiology Sukhyun Ryu and Benjamin J. Cowling}

Host Cell Factors That Interact with Influenza Virus Ribonucleoproteins Ecco Staller and Wendy S. Barclay

Induction and Evasion of Type-I Interferon Responses during Influenza A Virus Infection Raquel Muñoz-Moreno, Carles Martínez-Romero and Adolfo García-Sastre

Structure and Function of Influenza Polymerase Joanna M. Wandzik, Tomas Kouba and Stephen Cusack

H7N9 Influenza Virus in China Chengjun Li and Hualan Chen

H5 Influenza Viruses in Egypt Rabeh El-Shesheny, Ahmed Kandeil, Ahmed Mostafa, et al.
Antivirals Targeting the Neuraminidase Larisa Gubareva and Teena Mohan

Accessory Gene Products of Influenza A Virus Rute M. Pinto, Samantha Lycett, Eleanor Gaunt, et al.

Influenza Immunization in the Context of

Preexisting Immunity Susanne L. Linderman, Ali H. Ellebedy, Carl Davis, et al.

Hemagglutinin Structure and Activities Steven J. Gamblin, Sébastien G. Vachieri, Xiaoli Xiong, et al.

Live Attenuated Cold-Adapted Influenza Vaccines Kanta Subbarao

Next-Generation Influenza Vaccines Masaru Kanekiyo and Barney S. Graham

Selective Genome Packaging Mechanisms of Influenza A Viruses

Takeshi Noda

Systems Biological Analysis of Immune Response to Influenza Vaccination

Mario Cortese, Amy C. Sherman, Nadine G.

Rouphael, et al.

For additional articles in this collection, see http://perspectivesinmedicine.cshlp.org/cgi/collection/ 